\title{
The Interaction Model of the Regional People's Representative Council and Local Governments Regarding Timely Approval of the Regional Budget
}

\author{
Baharuddin Andang ${ }^{1}$, Amir Imbaruddin ${ }^{2}$, Hamsu Abdul Gani ${ }^{2}$, Muchlis Madani ${ }^{2}$ \\ ${ }^{1}$ Doctoral Candidate in Public Administration, State University of Makassar, Indonesia \\ ${ }^{2}$ Co-Promoter Professor of Public Administration State University of Makassar, Indonesia \\ Received: January 3, 2021 \\ Received in Revised: January 21, 2021 \\ Accepted: January 31, 2021
}

\begin{abstract}
This study aims to describe the interaction model of the Regional People's Representative Council and the regional government of Sidenreng Rappang Regency regarding the timely ratification of the Regional Budget (APBD). The method in this research is descriptive with a qualitative approach. The total number of informants was 16 (sixteen) people. Data / information is collected through interview techniques equipped with observation techniques. The data collected were analyzed using qualitative analysis techniques, namely interactive analysis models, then the results of the analysis were presented in narrative form. The result of the research shows that the interaction in the policy context involves various elements and elites who interact with each other, but the phenomenon that occurs is sometimes contravention which often occurs in the midst of elite interaction. The interaction takes place in the form of bargaining after there is a difference in perceptions of a number of program and activity nomenclature along with the nominal value stated in the draft draft. The interactions that occur between the actors of the Regional People's Representative Council (DPRD) and the Regional Government since the preparation of the General Budget Policy Temporary Budget Ceiling Priority (KUA-PPAS) to the determination of the APBD, have always been colored by dissociative, associative forms of interaction but finally resolved with a local wisdom approach.
\end{abstract}

Keywords: Interaction Model, Regional People's Representative Council, Budget

\section{Introduction}

Interaction is a foundation of relationships in the form of actions based on social norms and values that apply and are applied in society. With the prevailing values and norms, social interaction itself can run well if the existing rules and values can be implemented properly (Schwartz, 1999; Chong, 2000). If there is no awareness of the individual, then the social process itself cannot run as we expect. In everyday life, of course, humans cannot be separated from one another, they will always need to look for other individuals or groups to be able to interact or exchange ideas. Social interaction is a reciprocal influence between two parties, namely between individuals and individuals or groups with other groups to achieve certain goals (Walton \& McKersie, 1991; Keltner et al., 2008).

Intraction in a policy context involves various elements and elites who interact with each other, but the phenomenon that occurs is sometimes contravention that often occurs in the midst of elite interaction in conditions of social processes that are often present in public (Nahuis et al., 2012). Identification of the emergence of controversy arises when in the interaction of power elites are no longer aware of the norms or regulations that must be fulfilled, studied, or must be obeyed (Dalling, 2002; de Sardan, 2015). 
In relation to the political and bureaucratic elites above, the implementation of decentralization through Law Number 23 of 2014 concerning Regional Government has formed local political dynamics which have their own characteristics according to regional conditions. This dynamic can also be seen in the form of interaction between the DPRD as the political elite in the regions and the regional government as the bureaucratic elite in the regions, which is manifested in the policy formulation and policy implementation functions of the DPRD and local governments. The interaction between the two local government administering institutions is one of the factors that determine the success of public policy formulation, including the budget and implementation of government in the regions. The interaction between the DPRD and local governments in Sidenreng Rappang Regency in the formulation process of policy was colored with dynamics, especially in the process of formulating and discussing Regional Revenue and Expenditure Budget policies.

The interaction of the two local government administering agencies is one of the factors that determines the success of public policy formulation, including budget and implementation of government in the regions (Hall, 1999; Nurmandi \& Kim, 2015). Therefore, to formulate a good public policy, it requires commitment and partisanship of political elites and bureaucratic elites to consistently fight for the public interest above group or private interests.

As actors or policy elites do not stop at identifying policy problems, but must also fight for these issues / problems among various other issues / problems to enter into public action (agenda-setting) and become the agenda for formal discussions (Lawn \& Lingard, 2002; Liu et al., 2010). Agenda setting is a process that includes a series of actions and strategies in which a particular issue becomes the center of attention for the community. Even though it is an initial stage, agenda setting activities are difficult because they include identifying the correct problems (Birkland, 2007; Eissler et al., 2014).

Based on observations, the interaction between DPRD and local government occurs in an associative form, namely accommodative and cooperation that leads to unity of opinion. On the other hand, dissociative social interactions include competition, conflicts that lead to occasional conflicts, both during the KUA-PPAS discussion and during the RAPBD discussion, however after bargaining there is a compromise in order to fight for their respective interests. so that there are many criticisms of the DPRD and local governments due to the neglect of the leadership of the 'aspirations' of the community, both those proposed through the Mesrenbang process and those proposed through the DPRD member recess because they are not accommodated in the RAPBD. Therefore, this study aims to describe the interaction model of the Regional People's Representative Council and the local government of Sidenreng Rappang Regency regarding timely APBD approval.

\section{Methods}

The type of research used is descriptive with a qualitative approach, which provides an overview of the interaction between the DPRD and local governments in the process of formulating the Sidenreng Rappang Regency Regional Budget for the 2019 Fiscal Year. The scope of interaction in the focus of this study is the interaction between DPRD and local government when Meeting to discuss General Budget Policy and Temporary Budget Ceiling Priorities (KUA-PPAS) and discussion meeting on the Draft Regional Revenue and Expenditure Budget (RAPBD) held by the Regional People's Representative Council of Sidenreng Regency Rappang for the 2019 Fiscal Year.

The total number of informants was 16 (sixteen) people. Data / information is collected through interview techniques equipped with observation techniques. The data collected were analyzed using qualitative analysis techniques, namely interactive analysis models, then the 
results of the analysis were presented in narrative form. Data collection techniques are carried out by: Interview (Interview), Observation (Observation), and Documentation Technique (Documentation Technique). The data analysis steps used in this study are the Analysis Interactive Model from Miles et al (2014), namely data reduction, data presentation and conclusion drawing.

\section{Results and Discussion}

The interaction between the regional government and the Regional People's Representative Council (DPRD) of Sidenreng Rappang Regency in the discussion of the Draft Regional Revenue and Expenditure Budget (RAPBD), the results of which are determined through the Regional Regulation on APBD, cannot be separated from 2 (two) aspects, namely first, the mechanism for discussing the draft The Regional Revenue and Expenditure Budget (APBD) in effect in Sidenreng Rappang Regency, and the two interactions that occur between the DPRD and local governments at the stage of formulating the General Budget Policy Temporary Budget Ceiling Priority (KUA-PPAS) and the formulation of APBD policies in the form of Regional Regulations concerning Regional Revenue and Expenditure Budget, considering that overall this stage is part of a series of APBD policy formulation processes.

The absence of a concept of the main ideas of the DPRD will certainly have an impact on the APBD deliberation process in which the DPRD does not have comparable data which is the need of the community in general and the priorities that must be implemented. This condition was exacerbated by the lack of understanding of some members of the DPRD Budget Body when reading and reviewing the Work Plan and Budget of the Regional Apparatus Organization (RKA-OPD). On the other hand, this problem is also inseparable from the weaknesses of the regional government in terms of transparency because the various documents related to the complete RKA-OPD were not submitted to the DPRD Budget Board prior to the deliberation stage.

In fact, most documents such as the RKA of regional apparatus organizations will be submitted when the day before the discussion meeting is held, as a result the DPRD Budget Body experiences difficulties when suddenly they have to read, criticize and discuss the RAPBD, because they do not have sufficient time to study first before discussion is held, because The lack of understanding in reviewing the regional budget, debates between groups of actors cannot be avoided, especially in the discussion of the DPRD Budget Board and the Regional Government Budget Team which involves the Regional Apparatus Organizations to submit their RKA, although the members of the DPRD Budget Agency are dominating the proceedings. Furthermore, the debate arose due to the desire of the formulating actors from the DPRD Banggar who tried to change the nomenclature and the nominal value of the budget proposed by the Regional Apparatus Organization (OPD). The debate over actors is dominated by the DPRD Budget Agency actor group who try hard to defend their views, while on the other hand the formulating actors from the Regional Government Budget Team are sufficient to give an innocent response. The debate can be muted because the local government accepts proposals from DPRD members.

In connection with the actor debate above, one of the informants stated that: In every meeting between the TAPD and the DPRD Banggar, debate is inevitable due to differences in perceptions of the nominal value of the activity program, this is done with the intention of rationalizing the activity program delivered by the Regional Government Budget Team. But to avoid prolonged conflict, we usually resolve it with Sipakatau, Sipakalebbi and Sipakainge. (Interview with MZH, 22 November 2018. 
Thus steps were taken to build interaction and communication with members of the DPRD Budget Agency because after all the tug of war between the interests of each regional apparatus organizational unit to fight for its program to be financed by the regional budget. This interaction is generally built because there will be proposed OPD programs that are shifted, reduced and some even will be removed. As compensation, the formulating actors who are experienced in the relevant OPD environment use the non-formal interaction channel, namely (lobby), this is also usually done to ask members of the DPRD Banggar to increase their program budget allocation.

In the discussion of the RAPBD, the interaction between the regional government and the DPRD, everything is possible, including the dissociative counter-convention interaction that leads to disputes and even conflicts. But in the end, it was resolved with associativeaccommodative interactions based on local wisdom: Sipakatau, Sipakalebbi and Sipakainge so that a compromise occurred. Based on the author's observations, it is indicated that several programs that have been compiled by regional apparatus organizations are directly accommodated, including programs that are routine (recurring) every budget year, such as personnel spending, programs that touch the needs of many people, programs related to the vision and mission of the Regency. Sidenreng Rappang, as well as programs proposed by local governments that are in accordance with the results of the DPR members' recess, even programs whose costs are logical or rational do not undergo more serious discussion to be accommodated immediately.

Apart from the interaction of accommodation, in the discussion of the RAPBD, there was also a domination interaction between the local government (TPAD) and the DPRD Budget Agency. This condition occurred during the discussion of the RAPBD, where each regional apparatus organization presented its Budget Work Plan (RKA) in front of the DPRD Budget Board meeting, this is where the enormous dominance shown by members of the DPRD Budget Board, because they questioned the need for whether a program and / or activity is used, the nominal value of 'cost rationalization' is used and others, so it tends to be more dominant and uncompromising.

Most of the heads of regional apparatus organizations in describing their RKA seemed down in the face of pressure from council members. As a result, the impression that these two institutions had not formed a partnership as a regional government agency, in fact, was impressed that the DPRD Budget Agency was conducting interrogations with the regional government. In fact, in the context of this interaction, later on in formulating APBD policies, both should establish effective and synergistic communication and build a more accountable partnership.

Even if there are heads of regional government organizations who in their presentation are able to provide clear explanations and explanations to the questions of council members, they are heads of regional apparatus organizations who have the ability and courage or competence to understand their duties well or the heads of these regional apparatus organizations have a background. a good organization or perhaps the head of the regional apparatus organization concerned has the emotional relationship of some members of the council.

Likewise, the interaction of accommodation and dominance that occurred in the two groups of actors in the DPRD Budget Agency and the Regional Government Budget Team of Sidenreng Rappang Regency in the discussion of the Draft Regional Revenue and Expenditure Budget also found another pattern of relationship, namely the interaction in compromising the two groups of actors in compiling the budgeting policy in Sidenreng Rappang Regency. The results of the authors' observations conclude that the regional 
apparatus organizations (OPD) that have the potential for income or large revenues, in their discussion are always tough and have attractive attractiveness and use a long time, this situation and facts are certainly very worrying because the time provided is very limited. . If this condition drags on, it can result in a longer discussion. Therefore, a local wisdom approach is needed to solve it. This is in accordance with the opinion of one informant that:

In order to avoid conflict and protracted discussions between the Budget Agency and the Regional Government Budget Team, it is usually resolved "according to custom". (Interview with ESM, 23 November 2018).

In the writer's perception, the phrase 'customarily' means a Makassar Bugis local wisdom, namely: Sipakatau, Sipakalebbi and Sipakainge. This '3S' practice is very effective as an alternative solution in solving problems if the discussion drags on and sometimes even meetings are continued with additional schedules at night.

This condition is usually used by council members who have an interest in bargaining for programs and / or activities which in the end may end up with the Sipakatau, Sipakalebbi and Sipakainge approaches, so that for members of the DPRD Banggar and the Regional Government Budget Team, these bargaining efforts do not compromise agreements can be avoided.

The objective conditions seen in the plenary session of both the Level I Talk Meeting and the Level II Talk Meeting, the interaction between the Regional People's Representative Council and the Regional Government in the discussion process to the determination of the 2019 Budget Year above, both between the DPRD Budget Agency and the Regional Government Budget Team, and between the Regent of Sidenreng Rappang Ir. H. Dollah Mando and DPRD Chairman H. Zulkifi Zain also did not escape the process. This can be seen from the content of the speeches delivered by each policy actor, which is always agreed with the nuances of the values of Sipakatau, Sipakalebbi and Sipakainge. Although previously it was also marked by differences in perceptions that tended to lead to conflicts of interest of each actor from the two policy formulating institutions for the 2019 Regional Budget for Fiscal Year.

\section{Recommendations for the Interaction Model of Sipakatau, Sipakalebbi and Sipakainge as Solutions for Timely APBD Approval}

The practice of local wisdom mentioned above is in line with the results of the author's interview with one of the informants who stated that:

According to my experience during these three periods at the DPRD, every discussion of the Ranperda, including the Ranperda on APBD, there is always a fairly tough debate and sometimes even contradictions that have the potential to cause conflict, but in the end are resolved by means of, Sipakatau, Sipakalebbi and Sipakainge, either between fellow DPRD members as well as between DPRD members and SKPD heads. (Interview with ZHS, 5 November 2018).

Based on Permendagri Number 13 of 2006, the submission of the Regional Government Regulation on Regional Budget by the regional government to the DPRD should be the first week of October 2018. However, in Sidenreng Rappang Regency, there is a shift in time where the Regional Government submits the RAPBD on November 22, 2018. Then the Head of Sidenreng Rappang Regency DPRD issued a schedule discussion of the Draft Regional Revenue and Expenditure Budget (RAPBD), namely 23 to 30 November 2018.

The results showed that the interaction between the DPRD and the regional government of Sidenreng Rappang Regency occurred during the meeting to discuss the Draft APBD which 
was held at the DPRD building. In this stage, the submission of the draft regional budget for the 2019 Fiscal Year from the Regent of Sidenreng Rappang H. Ir. Dollah Mando to the Chairperson of the DPRD Sidenreng Rappang Regency was carried out through the DPRD Plenary Meeting which was held on November 22, 2018 at 09.00 (wita), at the Plenary Meeting Room of the DPRD Sidenreng Rappang Regency.

In the interaction between the local government and the DPRD, anything is possible, including the dissociative interaction of contravention that leads to disputes and even conflicts. But in the end, it was resolved with associative-accommodative interactions based on local wisdom: Sipakatau, Sipakalebbi and Sipakainge so that a compromise occurred. Based on the author's observations, it indicates that several programs that have been compiled by regional apparatus organizations are directly accommodated, including programs that are routine (recurring) every budget year, such as personnel spending, programs that touch the needs of many people, programs related to the vision and mission and programs proposed by the local government are in accordance with the results of the DPR members' recess, even rational programs are not discussed more seriously and then accommodated.

Most of the heads of regional apparatus organizations in describing their RKA seemed down in the face of pressure from council members. As a result, the impression that these two institutions had not formed a partnership as a regional government agency, in fact, was impressed that the DPRD Budget Agency was conducting interrogations with the regional government. In fact, in the context of this interaction, later on to formulate APBD policies, the two should establish effective and synergistic communication and build a more accountable partnership.

Even if there are heads of regional government organizations who in their presentation are able to provide clear explanations and explanations to the questions of council members, they are heads of regional apparatus organizations who have the ability and courage or competence to understand their duties well or the heads of these regional apparatus organizations have a background. A good organization or perhaps the head of the regional apparatus organization concerned has the emotional relationship of some members of the council.

In the writer's perception, the phrase 'customarily' means a Makassar Bugis local wisdom, namely: Sipakatau, Sipakalebbi and Sipakainge. This "3S" practice is very effective as an alternative solution in solving problems. This condition is usually used by council members who have an interest in bargaining for programs and / or activities which in the end can end up with the approaches of Sipakatau, Sipakalebbi and Sipakainge, to reach a compromise agreement.

The objective conditions seen in the plenary session of both the Level I Talk Meeting and the Level II Talk Meeting, the interaction between the Regional People's Representative Council and the Regional Government in the discussion process to the determination of the 2019 Budget Year above, both between the DPRD Budget Agency and the Regional Government Budget Team, and between the Regent of Sidenreng Rappang Ir. H. Dollah Mando and DPRD Chairman H. Zulkifi Zain also did not escape the process. The description of this conducive atmosphere can be assessed from the content of the speeches delivered by each policy actor, which is always agreed with the nuances of the values of Sipakatau, Sipakalebbi and Sipakainge. Although previously it was also marked by differences in perceptions that tended to lead to conflicts of interest of each actor from the two Budget policy formulating institutions. 
By trying to preserve the soul and spirit of "Nene Mallomo" with the principle of "Lempu, Getteng, Adatongeng", so that the fighting value according to the motto "Resopa Temmangingngi Namalomo Naletei Pammase Dewata" has always been an inspiration in determining policies in Sidenreng Rappang Regency. Given the importance of the role of '3Sipaka' local wisdom mentioned above, the authors recommend the '3Sipaka' Interaction Model in the policy formulation process as an alternative solution so that the ratification of the Regional Revenue and Expenditure Budget is always on time, as happened in Sidenreng Rappang Regency.

The conceptual model design of the interaction between DPRD and local government in the formulation of APBD policies is recommended and identified with the terminology "Sipakatau, Sipakalebbi and Sipakainge". Serves as a solution for timely approval of the APBD.

Direct threat Indirect threat

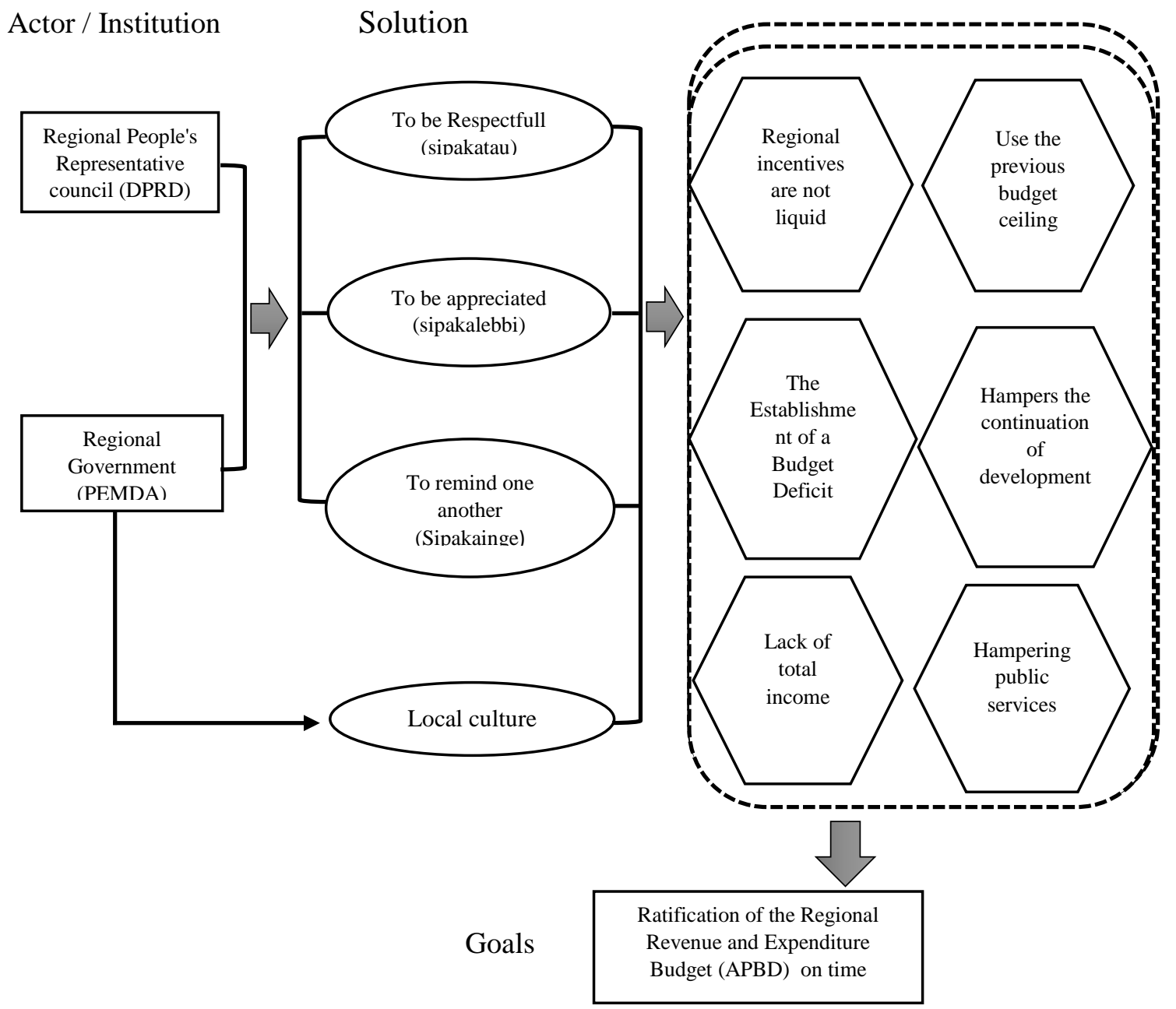

Figure 1. Design of the Interaction Conceptual Model of Sipakatau, Sipakalebbi and Sipakainge Solution for Timely APBD Approval

The identification results show several potential situations that could threaten if the APBD approval is late, but this condition is categorized as being able to be implemented according to the capacities of the actors of the two institutions, namely the DPRD and local governments in communicating and interacting. The design of a conceptual model of interaction between DPRD and local government in the formulation of recommended APBD policies and identified with the terminology "Sipakatau, Sipakalebbi and Sipakainge". Serves 
as a solution for timely approval of the APBD. By implementing a model of interaction between DPRD and local government in the formulation of the recommended APBD policies identified with the terminology "Sipakatau, Sipakalebbi and Sipakainge". Serves as a solution for timely approval of the APBD.

\section{Conclusion}

The interaction takes place in the form of bargaining after there is a difference in perceptions of a number of program and activity nomenclature along with the nominal value stated in the draft draft. The interactions that occur between the actors of the Regional People's Representative Council (DPRD) and the Regional Government since the preparation of the General Budget Policy - Temporary Budget Ceiling Priority (KUA-PPAS) to the determination of the Regional Revenue and Expenditure Budget (APBD), are always colored by dissociative, associative but finally resolved with local wisdom Sipakatau, Sipakalebbi and Sipakainge. This form of interaction has become a novelty in finding this research which is the solution for determining the APBD policy in Sidenreng Rappang Regency which is always on time for 13 (thirteen) consecutive years.

\section{References}

Birkland, T. A. (2007). Agenda setting in public policy. Handbook of public policy analysis: Theory, politics, and methods, 125, 63-78.

Chong, D. (2000). Rational lives: Norms and values in politics and society. University of Chicago Press.

Dalling, B. (2002). Administrative Wilderness: Protecting Our National Forestlands in Contravention of Congressional Intent and Public Policy. Nat. Resources J., 42, 385.

de Sardan, J. P. (2015). Practical norms: informal regulations within public bureaucracies (in Africa and beyond). Real governance and practical norms in Sub-Saharan Africa. London: Routledge.

Eissler, R., Russell, A., \& Jones, B. D. (2014). New avenues for the study of agenda setting. Policy Studies Journal, 42, S71-S86.

Hall, C. M. (1999). Rethinking collaboration and partnership: A public policy perspective. Journal of sustainable tourism, 7(3-4), 274-289.

Keltner, D., Van Kleef, G. A., Chen, S., \& Kraus, M. W. (2008). A reciprocal influence model of social power: Emerging principles and lines of inquiry. Advances in experimental social psychology, 40, 151-192.

Lawn, M., \& Lingard, B. (2002). Constructing a European policy space in educational governance: The role of transnational policy actors. European Educational Research Journal, 1(2), 290-307.

Liu, X., Lindquist, E., Vedlitz, A., \& Vincent, K. (2010). Understanding local policymaking: Policy elites' perceptions of local agenda setting and alternative policy selection. Policy Studies Journal, 38(1), 69-91.

Miles, M. B., Huberman, A. M., \& Saldana, J. (2014). Fundamentals of qualitative data analysis. Qualitative data analysis: A methods sourcebook, 69-104.

Nahuis, R., Moors, E. H., \& Smits, R. E. (2012). User producer interaction in context. Technological Forecasting and Social Change, 79(6), 1121-1134. 
Nurmandi, A., \& Kim, S. (2015). Making e-procurement work in a decentralized procurement system: A comparison of three Indonesian cities. International Journal of Public Sector Management.

Schwartz, S. H. (1999). A theory of cultural values and some implications for work. Applied psychology, 48(1), 23-47.

Walton, R. E., \& McKersie, R. B. (1991). A behavioral theory of labor negotiations: An analysis of a social interaction system. Cornell University Press. 